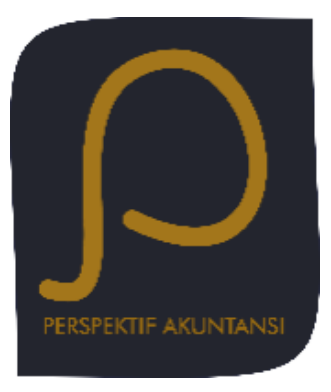

Perspektif Akuntansi

Volume 3 Nomor 3 (Oktober 2020), hal. 217-252

ISSN: 2623-0194 (Print), 2623-0186 (Online)

Copyright(C The Authors(s). All Rights Reserved

Center for Accounting Development and Research (CARD)

Program Studi Akuntansi

Fakultas Ekonomika dan Bisnis,

Universitas Kristen Satya Wacana

DOI: https://doi.org/10.24246/persi.vXiX.p217-252

http://ejournal.uksw.edu/persi

\title{
Penerapan Akuntansi Lingkungan Terhadap Pengelolaan Limbah Pabrik Pakan Ternak Pt Universal Agri Bisnisindo
}

\author{
Billy Josiah ${ }^{1}$ \\ Universitas Pembangunan Nasional “Veteran” Jakarta
}

Received

$21 / 01 / 2021$

Revised

09/09/2021

Accepted

09/02/2021

\begin{abstract}
This research aims to determine the implementation of environmental accounting in animal feed mills to the management of waste at Universal Agri Bisnisindo (UAB) animal feed mill. The method used in this research is qualitative method with an interpretive paradigm and ethnomethodology approach. The technique of data analysis used at the time of data collection in the form of interviews, observation, and documentation to key informants and supporting informants. The result of this research are that UAB animal feed mill has prevented the problem of waste properly. Have an IPAL machine that serves to reduce the occurrence of waste that comes out of the production process. UAB animal feed mill has implemented environmental accounting by identifying costs, recognizing costs, measuring costs, presenting costs, and disclosing costs which are the steps of accounting treatment for the management of factory waste. This company indentifies costs and recognizes environmental costs incurred as operating costs using the accrual basis method. Measurement using monetary units, by determining the amount of costs to be paid. This company presents environmental costs together with costs related to waste management.
\end{abstract}

Keywords: Environmental accounting, Animal feed mill, waste management, $U A B$ animal feed mill

1 billy.josiah@yahoo.com 


\begin{abstract}
Abstrak. Penelitian ini bertujuan untuk mengetahui bagaimana penerapan akuntansi lingkungan pada pabrik pakan ternak PT. Universal Agri Bisnisindo (UAB) terhadap pengelolaan limbah pabrik pakan ternak. Metode yang digunakan dalam penelitian ini adalah paradigma interpretatif dan metode etnometodologi. Teknik analisis data yang digunakan dalam pengumpulan data adalah wawancara, observasi dan pencatatan informan kunci dan informan pembantu. Hasil dari penelitian ini adalah pabrik pakan ternak PT. Universal Agri Bisnisindo mengatasi sampah dengan baik. Pabrik Pakan Ternak PT. Universal Agri Bisnisindo telah menerapkan akuntansi lingkungan yaitu dengan melakukan identifikasi biaya, pengakuan biaya, pengukuran biaya, penyajian biaya, dan pengungkapan biaya yang merupakan tahapan-tahapan dari perlakuan akuntansi untuk pengelolaan limbah pabrik. Pabrik telah menentukan biaya yang timbul dalam proses pengelolaan limbah, dan menggunakan basis akrual untuk mengakui biaya lingkungan yang timbul sebagai biaya operasi. Pabrik yang mengukur biaya pengelolaan limbah berdasarkan kilogram setelah diolah. Dengan menentukan jumlah biaya yang harus dibayar, satuan mata uang digunakan untuk pengukuran. Pabrik menyajikan biaya lingkungan dan biaya terkait pengelolaan limbah. Penyajian dan pengungkapan dilakukan bersama-sama sebagai biaya sub-operasi dalam akun beban administrasi dan umum.
\end{abstract}

Kata Kunci: Akuntansi lingkungan, limbah pabrik pakan ternak, pengelolaan limbah, PT UAB

\title{
Pendahuluan
}

Dengan semakin banyaknya studi tentang akuntansi lingkungan di Indonesia, penggunaan istilah akuntansi lingkungan akhir-akhir ini menjadi populer. Akuntansi lingkungan berkaitan dengan informasi lingkungan dan sistem audit lingkungan, dan mencakup identifikasi, pelacakan, analisis, pelaporan, dan informasi biaya yang berkaitan dengan aspek lingkungan organisasi. Adanya akuntansi lingkungan juga membantu mengatasi permasalahan lingkungan sosial, Selain itu, akuntansi lingkungan juga digunakan untuk pekerjaan perusahaan guna membantu tercapainya tujuan tanggung jawab perusahaan kepada stakeholders perusahaan. Pada dasarnya konsep akuntansi lingkungan mulai berkembang di Eropa pada tahun 1970-an, dan kemudian penelitian tentang masalah akuntansi lingkungan dikembangkan pada tahun 1980-an (Gray, Walters, Bebbington, \& Thompson, 1995).

Pada pertengahan 1990-an, Komite Standar Akuntansi Internasional (IASC) mengajukan konsep prinsip akuntansi internasional, termasuk pengembangan akuntansi lingkungan. Hal ini dilakukan karena dilihat dari manfaatnya memang akuntansi lingkungan cukup mempengaruhi kualitas kerja sebuah perusahaan. Menurut penelitian Dunk (2002) yang berjudul "Kualitas Produk, Akuntansi Lingkungan dan Kinerja Kualitas", dapat disimpulkan bahwa kegiatan akuntansi lingkungan telah memberikan kontribusi yang signifikan terhadap kualitas kinerja perusahaan. Akuntansi lingkungan juga menjadi sarana yang cukup membantu untuk 
mengatasi masalah-masalah lingkungan yang ada pada suatu negara. Di negara maju, perkembangan masalah lingkungan berkembang pesat baik secara teori maupun praktek. Banyaknya regulasi terkait lingkungan ini membuktikan hal tersebut. Di Indonesia, peraturan perundang-undangan yang terkait dengan lingkungan hidup diatur oleh Resolusi Nomor 32 Tahun 2009 tentang Perlindungan dan Lingkungan Hidup dalam Undang-Undang Republik Indonesia. Akuntansi lingkungan sangat penting karena perusahaan perlu mengkomunikasikan informasi tentang kegiatan sosial dan perlindungan lingkungan kepada pemangku kepentingan perusahaan. Perusahaan tidak hanya menyampaikan informasi keuangan kepada investor dan kreditor yang ada serta calon investor atau kreditor perusahaan, tetapi juga perlu memperhatikan manfaat sosial dari operasional perusahaan.

Dalam pengelolaan limbah produksi, perusahaan perlu menerapkan akuntansi lingkungan untuk mendukung kegiatan operasional, khususnya pengelolaan limbah produksi. Akuntansi lingkungan adalah bidang akuntansi yang fungsinya mengidentifikasi, mengukur, mengevaluasi, dan melaporkan akuntansi lingkungan. Dalam hal ini pencemaran dan limbah produksi merupakan contoh dampak negatif dari operasional perusahaan yang memerlukan sistem akuntansi lingkungan sebagai pengendalian atas tanggung jawab perusahaan. Penerapan akuntansi lingkungan juga bertujuan untuk mengetahui biaya lingkungan yang timbul dalam pengelolaan limbah melalui penggunaan sistem akuntansi, sehingga biaya dapat diminimalisir, tanggung jawab perusahaan dalam menjaga lingkungan sekitar perusahaan dapat dikendalikan, dan pelaporan biaya lingkungan dapat digunakan untuk pedoman manajemen dalam pengambilan keputusan dengan menerapkan akuntansi lingkungan, perusahaan juga dapat mengendalikan limbah produksi yang dikeluarkan agar limbah tersebut tidak mencemari lingkungan sekitar perusahaan.

Pabrik pakan ternak ini menjadi salah satu contoh sehingga pabrik - pabrik tidak membuang limbah hasil proses produksi dengan sembarangan, untuk menjaga kelangsungan dari pabrik tersebut. Bukan hanya untuk kelangsungan pabrik itu sendiri, tetapi juga untuk kelangsungan hidup makhluk-makhluk di sekitar pabrik, baik itu tumbuhan, hewan maupun manusia. Pada tahun 2009, pemerintah mengeluarkan Pasal 2 UU No. 32/2009 yang mengatur bahwa perlindungan dan pengelolaan lingkungan harus didasarkan pada prinsip partisipatif dan kearifan lokal. Artinya undang-undang menyatakan bahwa ia diperintahkan untuk melindungi dan menjaga lingkungan sekitar.

Sampai saat ini Indonesia belum memiliki peraturan atau standar akuntansi khusus untuk akuntansi lingkungan, tetapi pada PSAK No. 57 dijelaskan bahwa suatu entitas mempunyai aturan yang harus dijalankan sebagai tanggung jawab atau kewajiban entitas terhadap lingkungan sekitarnya yang disebut dengan provisi. Entitas mempunyai kebijakan pemeliharaan lingkungan tersendiri yang akan dipublikasikan dan reputasi entitas tersebut juga akan dilihat dari kebijakannya dalam memelihara lingkungan sekitar, Dalam hal ini, penyisihan tersebut diklasifikasikan sebagai kewajiban konstruktif. PSAK 33 juga menjelaskan biaya pengelolaan lingkungan untuk mengurangi dan mengendalikan dampak negatif dari aktivitas pencemaran lingkungan entitas. Mengubah kualitas lingkungan ke tingkat pencemaran lingkungan 
tertentu yang menyebabkan lingkungan menjadi semakin berkurang atau tidak dapat beroperasi sesuai dengan tujuannya.

Sesuai dengan Resolusi Pemerintah Republik Indonesia No. 47 tahun 2012 (Pemerintah Republik Indonesia, 2019), hal tersebut menyangkut tanggung jawab sosial dan lingkungan perseroan terbatas. Peraturan pemerintah ini mengatur tanggung jawab sosial dan lingkungan serta bertujuan untuk mewujudkan pembangunan ekonomi yang berkelanjutan guna meningkatkan taraf hidup yang bermanfaat bagi masyarakat sekitar dan seluruh masyarakat serta perusahaan itu sendiri dengan tetap menjaga hubungan perusahaan yang harmonis, seimbang dan selaras dengan kualitas lingkungan, nilai, norma dan budaya masyarakat setempat. Menurut peraturan pemerintah ini, pada dasarnya pemerintah membutuhkan pemahaman penuh terhadap perusahaan dan organisasi lain yang terkena dampak lingkungan. Ada alasan untuk melakukan penelitian di pabrik pakan ternak PT. UAB merupakan perusahaan yang bergerak dibidang pakan ternak yang banyak menggunakan bahan kimia yang menghasilkan limbah dan berdampak negatif terhadap lingkungan sekitarnya.

Peneliti mencoba memperoleh informasi apakah masalah mengenai tanggung jawab sosial dan lingkungan sekitar, dari hasil wawancara dengan petugas IPAL pabrik pakan ternak PT UAB, Bapak Ujang menjelaskan bahwa ada beberapa masalah pengelolaan limbah yang dihadapi pihak pabrik, seperti misalnya ada beberapa alat pengelolaan yang mengalami kerusakan berupa bocor dan berfungsi kurang baik. Sehingga hal tersebut dapat menyebabkan pencemaran lingkungan.

Pada kesempatan wawancara selanjutnya informasi yang didapatkan dari manager akuntan pada PT. UAB yang menjelaskan bagaimana melihat biaya - biaya yang dikeluarkan pihak pabrik untuk pengelolaan limbah dalam laporan keuangan dan juga dari dokumen - dokumen lainnya terkait biaya penanganan limbah.

Berdasarkan uraian latar belakang di atas maka penulis tertarik untuk mempelajari penerapan akuntansi lingkungan pada pabrik pakan ternak. Jadi ini adalah rumusan masalah yang ingin Anda pelajari: Bagaimana makna penerapan akuntansi lingkungan di Pabrik Pakan Ternak?

Tujuan dari penelitian ini adalah untuk mengetahui penerapan akuntansi lingkungan di Pabrik Pakan Ternak dalam upaya mengatasi masalah limbah yang dapat mencemarkan lingkungan apakah sudah sesuai dengan peraturan yang berlaku, dimana belum ada penelitian terdahulu mengenai penerapan akuntansi lingkungan pada pabrik pakan ternak. Manfaat teoritis meningkatkan pengetahuan tentang akuntansi lingkungan. Ilmu ini dapat digunakan untuk pengembangan yang berkaitan dengan akuntansi lingkungan. Dapat membantu terkait penghitungan untuk meningkatkan efisiensi dan memelihara reputasi yang baik untuk pabrik pakan ternak. Manfaat praktis diharapkan hasil penelitian ini dapat dijadikan sebagai salah satu acuan bagi pihak pabrik PT UAB ke depannya dalam menangani masalah pengelolaan limbahnya dan menggunakan akuntansi lingkungan lebih baik dari sebelumnya. 


\section{Telaah Pustaka}

\section{Pengertian Lingkungan}

Menurut Undang-Undang Nomor 32 (2009) Republik Indonesia (Perlindungan dan Pengelolaan Lingkungan pada Pasal 1 ayat 1) lingkungan didefinisikan sebagai:

"Lingkungan hidup adalah kesatuan ruang dengan semua benda, daya, keadaan, dan makhluk hidup, termasuk manusia, dan perilaku, yang mempengaruhi kelangsungan perkehidupan dan kesejahteraan manusia serta makhluk hidup lain."

\section{Pencemaran Lingkungan}

Pengertian pencemaran lingkungan sesuai dengan Pasal 1 ayat 14 Undang-Undang Nomor 32 Tahun 2009 Republik Indonesia adalah sebagai berikut:

"Pencemaran lingkungan hidup adalah masuk atau dimasukannya Makhluk hidup, zat, energy, dan/atau komponen lain ke dalam lingkungan hidup oleh kegiatan manusia sehingga melampaui baku mutu lingkungan hidup yang telah ditetapkan."

Pencemaran dapat disebabkan oleh aktivitas manusia atau alam (seperti letusan gunung berapi dan gas beracun). Ilmu lingkungan membahas tentang pencemaran yang disebabkan oleh aktivitas manusia yang dapat dicegah dan dikendalikan. Pencemaran lingkungan tidak dapat dihindari, tindakan yang dapat dilakukan adalah dengan mengurangi pencemaran, mengendalikan pencemaran, serta meningkatkan kesadaran dan perhatian masyarakat untuk menghindari pencemaran lingkungan.

\section{Akuntansi Lingkungan}

Akuntansi lingkungan (EA atau Green Accounting) adalah istilah yang terkait dengan memasukkan biaya lingkungan ke dalam praktik akuntansi perusahaan atau instansi pemerintah. Akuntansi lingkungan diartikan sebagai pencegahan, pengurangan dana atau penghindaran dampak lingkungan, mulai dari peluang, dari pemeliharaan, hingga kejadian yang menimbulkan bencana untuk kegiatan tersebut (Ikhsan, 2008). Pada dasarnya, akuntansi lingkungan membutuhkan pemahaman penuh tentang perusahaan dan organisasi lain yang mendapat manfaat dari lingkungan. Akuntansi lingkungan (AL) adalah istilah luas yang digunakan dalam banyak situasi berbeda (Ikhsan, 2008), misalnya: penilaian dan pengungkapan lingkungan terkait dengan informasi keuangan dalam ruang lingkup akuntansi dan pelaporan keuangan; melakukan penilaian lingkungan dan penggunaan informasi fisik dan keuangan dalam ruang lingkup akuntansi pengelolaan lingkungan; dan Perkiraan dampak dan biaya lingkungan eksternal biasanya disebut akuntansi biaya penuh (FCA).

Menurut Ikhsan, (2008), akuntansi lingkungan dapat dijelaskan lebih lanjut dalam dua bidang utama, yaitu: Akuntansi lingkungan keuangan, biasanya bidang akuntan yang menyiapkan laporan keuangan untuk kredit dan investor dan Melalui berbagai teknik alokasi biaya, evaluasi kinerja dan pengetahuan analisis bisnis, akuntansi 
lingkungan manajemen, dukungan manajemen internal dan proses manufaktur yang unik.

\section{Tujuan Penerapan Akuntansi Lingkungan}

Tujuan dari akuntansi lingkungan adalah untuk meningkatkan jumlah informasi relevan yang dibuat bagi mereka yang membutuhkan atau dapat menggunakannya. Tujuan lain dari keterbukaan informasi akuntansi lingkungan adalah terkait dengan kegiatan perlindungan lingkungan perusahaan dan organisasi lain, yang melibatkan kepentingan organisasi publik dan perusahaan lokal yang terdaftar. Menurut Ikhsan (2008), tujuan dan alasan pengembangan akuntansi lingkungan adalah sebagai berikut:

Akuntansi lingkungan adalah alat manajemen lingkungan. Sebagai alat manajemen lingkungan, akuntansi lingkungan digunakan untuk mengevaluasi efektivitas kegiatan perlindungan lingkungan. Data akuntansi lingkungan juga digunakan untuk menentukan biaya fasilitas pengelolaan lingkungan, biaya perlindungan lingkungan secara keseluruhan, dan investasi yang diperlukan untuk kegiatan pengelolaan lingkungan.

Akuntansi lingkungan merupakan alat komunikasi dengan publik. Sebagai alat komunikasi publik, akuntansi lingkungan digunakan untuk mengkomunikasikan dampak negatif lingkungan, kegiatan perlindungan lingkungan dan hasilnya kepada publik. Tanggapan dan pendapat komunitas digunakan sebagai umpan balik untuk mengubah perlindungan lingkungan atau praktik manajemen perusahaan.

\section{Pentingnya Akuntansi Lingkungan}

Menurut Ikhsan (2008), akuntansi lingkungan penting untuk diperhatikan semaksimal mungkin karena akuntansi lingkungan merupakan bagian dari akuntansi atau sub akuntansi. Alasan mendasarnya adalah bahwa ia mengarah pada partisipasinya dalam konsep ekonomi dan informasi lingkungan. Akuntansi lingkungan juga merupakan bidang yang berkembang dalam hal menentukan metrik dan mengkomunikasikan biaya aktual perusahaan atau potensi dampak terhadap lingkungan.

\section{Pengakuan Biaya Akuntansi Lingkungan}

Konfirmasi adalah mencatat jumlah rupee dalam sistem akuntansi sehingga jumlah tersebut mempengaruhi suatu barang dan akan tercermin dalam laporan keuangan (Suwardjono, 2013). Menurut standar identifikasi FASB terdapat empat aspek yaitu definisi, keterukuran, relevansi dan reliabilitas. Berdasarkan standar ini, biaya pembuangan limbah dapat dikonfirmasi dan dicatat dalam sistem pencatatan, yang akan mempengaruhi laporan keuangan. Ini didasarkan pada kondisi berikut: Menurut definisi, pembuangan limbah dianggap sebagai pengeluaran karena mengurangi pemerataan atau kekayaan daerah; Dapat diukur bahwa biaya yang dikeluarkan dapat diukur dalam satuan moneter, berdasarkan jumlah yang dikeluarkan oleh fasilitas sanitasi sebagai penyedia pengolahan limbah; Relevance, Biaya tersebut karena adanya pembuangan limbah dari kegiatan pelayanan kesehatan kepada 
masyarakat; dan Kehandalan biaya-biaya yang dikeluarkan tersebut dapat dipertanggungjawabkan oleh sanitasi sebagai salah satu pusat biaya. Dalam paragraf 84 Kerangka Konseptual Akuntansi Pemerintah SAP, konfirmasi akuntansi adalah proses untuk menentukan apakah kriteria untuk merekam suatu peristiwa atau beberapa peristiwa dalam catatan akuntansi terpenuhi, sehingga menjadikannya aset, kewajiban, ekuitas, pendapatan LRA, pengeluaran, pembiayaan, Bagian tambahan dari pokok pendapatan dan elemen lain yang berkaitan dengan laporan keuangan entitas pelapor.

\section{Biaya Lingkungan}

Menurut Ikhsan (2008), biaya lingkungan adalah dampak moneter atau non moneter dari aktivitas perusahaan yang mempengaruhi kualitas lingkungan. Definisi biaya lingkungan mencakup semua biaya yang paling nyata (seperti limbah) untuk mengukur ketidakpastian. Biaya lingkungan pada dasarnya terkait dengan biaya produksi, proses, sistem, atau fasilitas yang penting untuk keputusan manajemen yang lebih baik. Biaya lingkungan termasuk biaya internal dan eksternal, dan terkait dengan kerusakan dan perlindungan lingkungan (Ikhsan, 2008). Sebelum memberikan informasi biaya lingkungan kepada manajemen, biaya lingkungan harus ditetapkan. Biaya lingkungan bisa disebut biaya kualitas lingkungan. Serupa dengan biaya kualitas, biaya lingkungan adalah biaya yang timbul karena kualitas lingkungan yang buruk atau kemungkinan kualitas lingkungan yang buruk. Menurut Nilasari (2014), biaya lingkungan:

Satu jenis. Pengeluaran perlindungan lingkungan adalah pengeluaran untuk kegiatan yang dilakukan untuk mencegah terjadinya limbah dan / atau limbah yang dapat merusak lingkungan. Contoh kegiatan pencegahan meliputi evaluasi dan pemilihan pemasok, evaluasi dan pemilihan alat pengendalian pencemaran, desain proses dan produk pengurangan atau penghapusan limbah, pelatihan karyawan, penelitian tentang dampak lingkungan, audit risiko lingkungan, penelitian lingkungan, pengembangan sistem manajemen lingkungan, Pengerjaan ulang produk secara berkala dan mendapatkan sertifikat ISO 14001.

Biaya pengujian lingkungan merupakan biaya kegiatan lain di perusahaan yang memenuhi atau tidak memenuhi standar lingkungan yang berlaku. Contoh kegiatan pengujian lingkungan antara lain meninjau kegiatan lingkungan, memeriksa produk dan proses (ramah lingkungan), merumuskan ukuran kinerja lingkungan, melakukan uji polusi, memverifikasi kinerja lingkungan pemasok, dan mengukur tingkat polusi.

Biaya kerusakan lingkungan mengacu pada biaya kegiatan yang dilakukan karena timbulan limbah dan sampah, tetapi tidak dibuang ke lingkungan luar. Contoh aktivitas kegagalan internal termasuk pengoperasian peralatan untuk mengurangi atau menghilangkan polusi, pengolahan dan pembuangan limbah beracun, pemeliharaan peralatan pencemar, fasilitas izin untuk menghasilkan limbah, dan daur ulang limbah.

Biaya kegagalan lingkungan eksternal adalah biaya kegiatan yang dilakukan setelah pembuangan limbah atau sampah ke lingkungan. Contoh kegiatan eksternal yang 
gagal termasuk membersihkan tanah yang terkontaminasi, menyelesaikan klaim untuk kecelakaan pribadi (terkait dengan lingkungan), memulihkan tanah ke keadaan aslinya, kehilangan penjualan karena reputasi lingkungan yang buruk, penggunaan bahan baku dan listrik yang tidak efisien, menerima perawatan medis karena polusi, Kehilangan lapangan kerja yang disebabkan oleh pencemaran, hilangnya pemanfaatan danau sebagai tempat rekreasi, dan kerusakan ekosistem oleh pembuangan limbah padat.

\section{Tahap-Tahap Perlakuan Alokasi Biaya Lingkungan}

Pengelompokan tahap analisis lingkungan yang ditetapkan dalam Pernyataan Standar Akuntansi Keuangan (PSAK) 2009 adalah sebagai berikut:

\section{Identifikasi}

Untuk pertama kalinya, perusahaan akan menentukan biaya pengelolaan eksternalitas yang mungkin terjadi dalam operasi bisnisnya sebagai dampak negatif tersebut. Misalnya, rumah sakit yang diperkirakan menghasilkan limbah B3 memerlukan perlakuan khusus untuk mengidentifikasi kemungkinan adanya limbah, antara lain limbah padat, cair atau radioaktif dari kegiatan instalasi rumah sakit atau aktivitas karyawan (Hadi, 2012).

\section{Pengakuan}

Jika sudah teridentifikasi, maka akan diakui sebagai akun atau akun beban pada saat pendapatan diterima dari jumlah yang digunakan untuk pembiayaan lingkungan. Biaya bulanan perusahaan untuk pengelolaan limbah perusahaan dikumpulkan dari biaya yang telah dicadangkan atau dianggarkan sebelumnya, yaitu melalui pembiayaan dimuka.

\section{Pengukuran}

Pengukuran adalah menentukan besaran atau satuan ukuran suatu benda untuk menunjukkan makna tertentu dari benda (Suwardjono, 2013). Biasanya, perusahaan menggunakan unit mata uang yang telah ditentukan dan jumlah uang yang dikeluarkan untuk mengukur biaya pengelolaan lingkungan perusahaan. Dapatkan jumlah dan nilai yang tepat sesuai dengan kebutuhan aktual perusahaan di setiap periode.

\section{Penyajian}

Biaya yang dikeluarkan oleh pengelolaan lingkungan didaftar bersama dengan biaya satuan serupa lainnya di sub-biaya umum dan administrasi. Biaya lingkungan ini dapat ditampilkan dalam laporan keuangan atau dengan nama akun yang berbeda, karena tidak ada ketentuan standar untuk menetapkan nama akun pembiayaan lingkungan perusahaan.

\section{Pengungkapan}

Pengungkapan berkaitan dengan bagaimana menerima atau menginterpretasikan informasi yang penting dan berguna bagi pengguna laporan keuangan. Sesuai dengan standar akuntansi yang memuat informasi atau objek, harus dicantumkan secara 
terpisah dari laporan utama, apakah perlu untuk menentukan suatu item atau apakah informasi tersebut disediakan secara memadai dalam bentuk catatan kaki (Suwardjono, 2013).

\section{Sistem Akuntansi Lingkungan}

Sistem akuntansi lingkungan meliputi akuntansi konvensional dan akuntansi ekologi. Akuntansi lingkungan tradisional menggunakan istilah keuangan untuk mengukur dampak lingkungan alam pada perusahaan. Akuntansi ekologi berupaya mengukur dampak perusahaan berdasarkan lingkungan, tetapi diukur dalam satuan fisik (sisa produk dalam kilogram, dan konsumsi energi dalam kilojoule), tetapi standar pengukuran yang digunakan tidak dalam bentuk satuan keuangan.

\section{Ruang Lingkup Akuntansi Lingkungan}

Terdapat dua bagian dalam Lingkup akuntansi lingkungan. Bagian pertama didasarkan pada aktivitas akuntansi lingkungan perusahaan di negara dan wilayah. Bagian kedua memperkenalkan akuntansi lingkungan perusahaan dan organisasi lain.

\section{Fungsi dan Peran Akuntansi Lingkungan}

Fungsi dan peran akuntansi lingkungan menggambarkan pentingnya penggunaan akuntansi lingkungan di perusahaan atau organisasi lain. Fungsi dan peran tersebut terbagi menjadi dua bentuk. Fungsi pertama disebut fungsi internal, dan fungsi kedua disebut fungsi eksternal (Ikhsan, 2008). Masing-masing fungsi ini dijelaskan di bawah:

\section{Fungsi Internal}

Fungsi internal adalah fungsi yang terkait dengan semua pihak dalam perusahaan. Pihak internal adalah pihak yang menyelenggarakan usaha, seperti rumah tangga konsumen dan rumah tangga produksi dan jasa lainnya. Adapun pelaku dan faktor dominan dari fungsi internal ini adalah pimpinan perusahaan. Karena pemimpin perusahaan adalah orang yang bertanggung jawab untuk mengambil keputusan dan menentukan kebijakan dalam perusahaan. Menerapkan akuntansi lingkungan dapat membantu pemimpin dalam semua aspek yang berkaitan dengan pengelolaan lingkungan, tidak hanya mencatat biaya lingkungan yang dikeluarkan.

\section{Fungsi Eksternal}

Fungsi eksternal adalah fungsi yang berkaitan dengan pelaporan keuangan. Fungsi tersebut merupakan faktor penting yang perlu diperhatikan oleh perusahaan sebagai hasil dari kegiatan perlindungan lingkungan masyarakat berupa data akuntansi. Informasi yang diungkapkan merupakan pengukuran kuantitatif dari kegiatan perlindungan lingkungan. Ini termasuk informasi tentang sumber daya ekonomi perusahaan. Fungsi eksternal memberi perusahaan hak untuk mempengaruhi keputusan pemangku kepentingan, seperti pelanggan, mitra bisnis, investor, penduduk lokal dan departemen administrasi. 
Mulai dari fungsi dan peran akuntansi lingkungan, akan dipelajari penerapan akuntansi lingkungan di pabrik pakan ternak. Tujuannya untuk memahami bagaimana seluruh pabrik menerapkan akuntansi lingkungan dari pengelolaan lingkungan dan pencatatan yang menimbulkan biaya lingkungan.

\section{Jenis Bahan Pakan Ternak}

Jenis bahan pakan ternak dibedakan menjadi bahan pakan yang berasal dari tumbuhan atau bahan pakan yang diperoleh dari hasil pertanian, bahan pakan hewani atau bahan pakan berbasis hasil perikanan, dan pakan tambahan limbah yang biasanya diproduksi di pabrik, yang biasanya digunakan untuk melengkapi atau memperbaiki keseimbangan nutrisi. Pakan nabati menyumbang 90-94\% dari total ransum ternak non-invasif. Hal ini dikarenakan bahan pakan nabati biasanya merupakan sumber energi yang harus selalu terpenuhi saat jatah diberikan ransum.

\section{Limbah Berdasarkan Jenis Senyawanya}

Menurut (Arif, 2014), limbah dikelompokkan menurut jenis senyawanya yaitu limbah organik, limbah anorganik, dan limbah bahan berbahaya dan beracun (B3). Limbah organik adalah sampah makhluk hidup yang mudah terurai atau terurai. Limbah anorganik adalah segala jenis sampah yang tidak dapat atau sulit terurai secara alami oleh mikroorganisme pengurai. Limbah bahan berbahaya dan beracun (B3) adalah sekumpulan limbah yang secara langsung maupun tidak langsung dapat mencemari, membahayakan lingkungan, kesehatan, dan kelangsungan hidup manusia serta organisme lain.

\section{Karakteristik Limbah}

Menurut (Arif, 2014), menurut karakteristik sampah, sampah dibedakan menjadi empat bagian yaitu limbah padat, limbah cair, limbah gas, dan limbah bahan berbahaya dan beracun. Limbah padat atau sampah adalah sampah yang tidak lagi digunakan oleh rumah tangga atau pabrik atau tidak lagi digunakan dalam bentuk padat. Sampah merupakan sampah paling melimpah di lingkungan. Menurut PP No. Resolusi Nomor 82 Tahun 2001 menyatakan bahwa limbah cair adalah sisa produk atau aktivitas yang berbentuk cair. Limbah cair atau air limbah mengacu pada kelebihan air buangan dari rumah tangga, industri dan tempat umum lainnya, dan biasanya mengandung bahan atau zat yang dapat membahayakan kesehatan manusia dan merusak lingkungan.

Menurut Azwar (1990), limbah cair mengacu pada air yang tidak murni yang mengandung berbagai zat yang membahayakan kehidupan manusia atau hewan dan tumbuhan, serta merupakan aktivitas manusia, seperti limbah industri dan sampah rumah tangga. Industri melepaskan berbagai polutan ke dalam air limbah, seperti logam berat, minyak bumi, nutrisi, dan padatan. Air limbah memiliki efek termal dan dapat mengurangi oksigen di dalam air, seperti air limbah pabrik yang mengalir ke sungai. 
Polusi udara mengacu pada keberadaan satu atau lebih zat fisik, kimia atau biologi di atmosfer, yang dapat membahayakan kesehatan manusia, hewan dan tumbuhan, merusak keindahan dan kenyamanan, atau merusak properti. Pencemaran udara dapat disebabkan oleh sumber daya alam dan aktivitas manusia. Sifat alami udara menyebabkan efek pencemaran udara bersifat lokal, regional dan global. Banyak faktor yang dapat menyebabkan pencemaran udara, antara lain pencemaran yang disebabkan oleh sumber daya alam atau aktivitas manusia atau kombinasi keduanya. Pencemaran udara akan menimbulkan pengaruh langsung dan tidak langsung pencemaran udara dalam jangka waktu yang lama.

Polutan udara dibedakan menjadi polutan primer dan sekunder. Pencemar utama adalah pencemar yang dihasilkan langsung dari sumber pencemaran udara. Karbon monoksida adalah salah satu contoh pencemar udara utama karena merupakan hasil pembakaran. Polutan sekunder adalah polutan yang terbentuk dari reaksi polutan utama di atmosfer. Dampak kesehatan yang mungkin timbul adalah polutan di udara dapat masuk ke tubuh manusia melalui pernapasan. Menurut PP 18 tentang pengelolaan limbah B3 tahun 1999, limbah B3 diartikan sebagai sisa usaha dan / atau kegiatan yang mengandung bahan berbahaya dan / atau beracun yang dapat mencemari secara langsung dan / atau karena sifat dan / atau konsentrasi dan / atau kuantitasnya. Atau merusak lingkungan. Kehidupan dan / atau membahayakan lingkungan, kesehatan, kelangsungan hidup manusia dan organisme lain.

Limbah B3 menurut BAPEDAL (1995) adalah setiap zat sisa (limbah) dalam proses produksi yang bersifat toksik, mudah terbakar, reaktivitas dan korosif, serta konsentrasi atau jumlah yang dapat dimusnahkan secara langsung maupun tidak langsung mengandung zat berbahaya dan beracun ( B3). , Mencemari lingkungan atau membahayakan kesehatan manusia.

\section{Penanganan Limbah}

Menurut Arif (2014), penanganan limbah dibagi menjadi tiga, yakni limbah padat, limbah cair, dan limbah gas. Limbah padat dapat ditangani dengan cara: penimbunan (metode open dumping dan sanitary landfill), insinerasi, pembuatan kompos. Beberapa metode sederhana untuk mengolah limbah cair atau air limbah antara lain: pengenceran atau pengenceran, kolam oksidasi, irigasi. Beberapa metode pengendalian pencemaran udara oleh gas buang dan partikulat yang terkandung di dalam gas buang: mengontrol emisi gas buang dan membuang materi partikulat dalam gas buang. 


\section{Metoda}

\section{Metode Penelitian Kualitatif}

Berdasarkan rumusan masalah tersebut maka metode penelitian yang sesuai yang digunakan dalam penelitian ini adalah metode kualitatif deskriptif. Penelitian kualitatif adalah penelitian yang dapat dianalisis tanpa melakukan prosedur analisis statistik. Menurut Moleong (2017), penelitian kualitatif bertujuan untuk memahami fenomena yang dialami oleh objek penelitian secara holistik dan deskriptif, seperti perilaku, persepsi, dan lain-lain, dengan menggunakan berbagai metode alamiah. Penelitian kualitatif didasarkan pada latar belakang alam secara keseluruhan, memposisikan manusia sebagai alat penelitian. Penelitian kualitatif adalah menggali dan memperdalam fenomena sosial atau lingkungan sosial yang terdiri dari partisipan, peristiwa, tempat, dan waktu.Oleh karena itu, penggambaran latar belakang sosial tersebut dapat menimbulkan pertanyaan mendasar: bagaimana peristiwa terjadi, bagaimana, objek, waktu, dan waktu. lokasi. Landasan penelitian kualitatif adalah usaha untuk membentuk pendapat yang didasarkan pada pendapat subjek yang diteliti.Dengan kata lain, penelitian kualitatif berusaha untuk melihat pendapat yang ada dalam penelitian.

Dibandingkan dengan metode penelitian kuantitatif, pemilihan metode penelitian deskriptif kualitatif karena penelitian tidak didasarkan pada pengujian statistik, tetapi berdasarkan masalah yang akan diteliti, dengan menekankan pandangan dan penalaran objek penelitian pada pernyataan akuntansi lingkungan pada PT. UAB. Oleh karena itu, tujuan dari penelitian ini adalah untuk dapat menjelaskan dan menjelaskan bagaimana memperkenalkan akuntansi lingkungan untuk pengelolaan sampah pada perusahaan yang dijadikan lokasi penelitian. Penelitian ini mengadopsi rangkaian metode natural berdasarkan sejumlah besar data yang telah terkumpul, kemudian dilakukan uji validitas datanya dan dianalisis untuk menarik kesimpulan.

\section{Pendekatan Penelitian}

Pendekatan dalam penelitian kualitatif merupakan bagaimana cara berpikir dalam pelaksanaan penelitian. Pendekatan dalam penelitian akan menguraikan maksud dari penelitian itu sendiri. Pendekatan yang digunakan dalam penelitian ini adalah pendekatan etnometodologi. Menurut Moleong (2017), Etnometodologi adalah studi tentang bagaimana individu menciptakan dan memahami kehidupan sehari-hari. Etnometrik mencoba memahami bagaimana orang memandang, menjelaskan, dan menggambarkan tatanan dunia tempat mereka tinggal. Moleong juga menunjukkan bahwa menurut ahli etnometrologi, penelitian bukanlah upaya ilmiah yang unik, tetapi solusi praktis.

Etnometodologi pertama kali dikemukakan oleh Harold Garfinkel pada pertengahan 1950-an. Gafinkel mendefinisikan metodologi etnis sebagai penyelidikan keseluruhan dari ekspresi indeks dan operasi praktis lainnya. etnometodologi menitikberatkan pada penjelasan proses interaksi dan cara para aktor mengkonstruksi perilaku sosial dalam realitas sehari-hari. Lintasan lintasan 
metodologi etnis berfokus pada bagaimana objek penelitian menginterpretasikan struktur atau definisi sosial ketika bersama-sama (Susilo, 2017).

Metode metodologi rasial berbeda dari metode lain karena merupakan metode mengamati perilaku individu ketika mengambil tindakan. Etnometodologi adalah salah satu bidang penelitian kualitatif, dan fokus penelitian kualitatif adalah studi tentang realitas eksplanatori praktis. Metode etnometodologi menghasilkan data deskriptif, yaitu data yang diperoleh dari tuturan, tulisan, dan observasi perilaku. Sehingga dapat dikatakan bahwa etnometodologi akan mencoba menjelaskan peran aktor sosial dalam tindakan dan menjelaskan tatanan dunia tempat mereka hidup.

Mengetahui proses penyajian akuntansi lingkungan pada situs penelitian merupakan proses dari penelitian ini. Penelitian ini juga bermaksud untuk meneliti sebab yang melatarbelakangi pemilihan metode yang digunakan, serta kendala-kendala yang dihadapi serta dampak yang timbul akibat pemilihan metode tersebut dalam laporan keuangan PT UAB dengan pendekatan etnometodologi, peneliti akan berusaha memahami bagaimana informan bertindak dalam perlakuan akuntansi lingkungan atas pengolahan limbah.

\section{Teknik Validitas Data}

Validitas atau pentingnya data dalam penelitian kualitatif sangat penting, karena penelitian kualitatif harus mengungkapkan fakta yang objektif. Triangulasi adalah teknik yang menggunakan sesuatu selain data yang diperoleh untuk pemeriksaan data atau perbandingan dengan data yang diperoleh. Teknik ini adalah teknik jaminan efektivitas yang paling umum digunakan dalam penelitian kualitatif.

Menurut Sugiyono (2014), jika triangulasi dilakukan, sebenarnya peneliti sedang mengumpulkan data, yang sekaligus menguji kredibilitas data. Triangulasi dilakukan dengan menggunakan teknologi data dan berbagai sumber data untuk mengecek kredibilitas data. Dalam pembagian jenis, triangulasi dibagi menjadi tiga jenis, yaitu triangulasi sumber, triangulasi teknis, dan triangulasi waktu. Penelitian ini menggunakan triangulasi sumber, yaitu dilakukan dengan meneliti data yang telah dikumpulkan melalui berbagai sumber. Pemeriksaan dilakukan dengan membandingkan dan menelaah kembali informasi yang diperoleh dari hasil wawancara antara satu informan dengan informan lainnya, dan membandingkan kunjungan tersebut dengan isi dokumen yang bersangkutan.

\section{Teknik Analisis Data}

Kesimpulan hanya dapat diambil setelah menganalisis data yang dikumpulkan. Analisis data akan menentukan apakah hasil penelitian akan menjawab pertanyaanpertanyaan yang telah diajukan. Analisis data merupakan alat yang digunakan untuk memecahkan dan memecahkan masalah yang dihadapi. Penelitian ini menggunakan teknologi analisis data model Miles dan Huberman, yang dilakukan melalui tiga kegiatan analisis data yaitu analisis data simultan, representasi data dan grafik kesimpulan. 
Reduksi data adalah proses memilih, menyederhanakan, memisahkan, dan mengubah data yang dikumpulkan. Reduksi data bertujuan untuk mempertajam, mengklasifikasikan, memandu, menghilangkan data yang tidak perlu dan mengatur data dengan cara ini. Data yang telah direduksi akan dikumpulkan secara terorganisir dan ditampilkan dalam bentuk deskriptif atau matriks untuk dilakukan proses analisis lebih lanjut.

Menarik kesimpulan setelah memverifikasi data yang diberikan. Kesimpulan bisa menjawab pertanyaan-pertanyaan yang telah diajukan, tapi mungkin juga tidak. Kesimpulan yang ditarik bisa bersifat final atau sementara. Kesimpulan sementara mengharuskan peneliti untuk mengumpulkan beberapa data tambahan guna menghasilkan kesimpulan akhir.

\section{Situs Penelitian}

Situs penelitian pada penelitian ini ialah PT UAB. PT. Universal Agri Bisnisindo melakukan kegiatan industri yang bergerak di bidang produksi pakan ternak khususnya pakan ternak ayam, ikan dan udang yang berlokasi di Jl. Raya Narogong KM 13,5, RT.001, RT. 006, Kelurahan Cikiwul, Kecamatan Bantar Gebang, Kota Bekasi 17152 dengan luas lahan kurang lebih $90.628 \mathrm{~m}^{2}$. Industri pakan ternak PT. Universal Agri Bisnisindo mulai berdiri sejak tahun 1999 sesuai dengan Akta Pendirian Perusahaan No.6 Tanggal 11 Februari 1999, bergerak di bidang industri pakan ternak. Kegiatan pakan ternak ini menggunakan bermacam bahan baku di antaranya bungkil kedelai, tepung daging, calcium, pollard, dedak, minyak kelapa sawit, tepung bulu ungas dan bahan penolong berupa obat-obatan/vitamin. Beberapa bahan baku tersebut banyak disuplai dari dalam negeri seperti Sulawesi, Jawa Timur, Jawa Tengah, Sumatera, Jawa Barat, Kalimantan, serta luar negeri seperti Australia, New Zealand, Amerika Latin, Argentina dan Brazil.

\section{Jenis dan Sumber Data}

Data merupakan salah satu komponen penelitian, yang berfungsi sebagai informasi yang dapat dipertanggungjawabkan. Jenis data yang digunakan dalam penelitian ini adalah data primer dan data sekunder. Dalam penelitian ini data primer yang digunakan berupa hasil wawancara langsung dengan narasumber pihak pabrik dan melakukan observasi lingkungan sekitar pabrik. Data pembantu dari penelitian ini berupa soft file dokumen - dokumen yang dikirim oleh pihak pabrik melalui internet maupun hardcopy.

\section{Teknik Pengumpulan Data}

Pengumpulan data merupakan suatu metode yang digunakan untuk memperoleh data yang akan diolah sebagai hasil penelitian. Keberhasilan pengumpulan data akan sangat bergantung pada kemampuan peneliti dalam menginterpretasikan data. Penelitian ini menggunakan data primer dan sekunder yang dikumpulkan melalui teknik wawancara dan dokumentasi. 


\section{Wawancara}

Informan dalam penelitian terdiri dari: Bapak Ujang selaku Staff dari pengelola IPAL, Ibu Lina selaku manager akuntansi di PT UAB, Bapak Bireven kepala staff bagian hukum

\section{Dokumentasi}

Data yang didapat dari hasil dokumentasi berupa dokumen - dokumen seperti laporan keuangan perusahaan, data transaksi biaya pengelolaan limbah, dokumen SOP pabrik PT UAB untuk melakukan pengelolaan limbah.

\section{Hasil dan Pembahasan}

\section{Limbah Kegiatan Operasional Pabrik Pakan Ternak PT. UAB}

Kegiatan produksi dan non produksi pabrik pakan ternak akan menghasilkan berbagai limbah yang sebagian diantaranya merupakan limbah berbahaya yang harus diolah secara khusus sebelum dibuang. Pabrik menghasilkan dua bentuk limbah. Selaku pengelola IPAL, Bapak Ujang mengungkapkan bahwa pabrik PT UAB menghasilkan 2 jenis limbah yaitu limbah cair dan limbah padat.

\section{Limbah Cair}

Limbah cair dari pabrik PT UAB ini berasal dari laboratorium dan domestik. Limbah cair laboratorium berasal dari kegiatan Proximate Analysis terhadap bahan baku maupun bahan jadi. Debit air limbah yang dihasilkan dari kegiatan ini sebesar $1 \mathrm{~m}^{3}$ /hari. Sedangkan limbah cair domestik berasal dari kegiatan mandi cuci kakus (MCK) karyawan, tamu pabrik dan air wudhu. Debit air yang dihasilkan dari kegiatan ini sebesar kurang lebih $27,5 \mathrm{~m}^{3} /$ hari.

\section{Limbah Padat}

Limbah padat yang dihasilkan dari kegiatan industri PT Universal Agri Bisnisindo meliputi limbah bahan berbahaya dan beracun (B3) dan limbah non B3. Limbah padat B3 berasal dari kegiatan produksi, kegiatan maintenance, kegiatan kantor berupa lampu tl, kain majun bekas, sarung tangan bekas, filter oli bekas, dan lain sebagainya. Sedangkan limbah padat non B3 berasal dari kegiatan kantor, kantin dan sampah halaman berupa sampah kertas, kardus, plastic, tissue, sisa makanan, daun-daun kering yang berjatuhan dan sebagainya. Jumlah limbah padat non B3 yang dihasilkan sekitar $144 \mathrm{~kg} /$ hari.

\section{Pengelolaan Limbah Pabrik}

Limbah pabrik yang dihasilkan dari berbagai aktivitas pabrik baik limbah dari proses produksi maupun bukan. Limbah yang dihasilkan dari kegiatan operasional Pabrik PT. Universal Agri Bisnisindo yaitu berupa limbah padat dan limbah cair. Cara pengelolaan limbah tersebut berbeda-beda khususnya limbah B3, karena akan membahayakan lingkungan sekitar akibat racun yang dicemarkan dari limbah tersebut. Proses pengelolaan limbah di Pabrik PT. Universal Agri Bisnisindo. Untuk 
mengelola limbah cair, pabrik menyediakan instalasi pengolahan air limbah (IPAL), Pembuatan saluran terpisah untuk air hujan dan limbah. Limbah cair tersebut meliputi limbah yang berasal dari: WC/kamar mandi, dapur, Laboratorium. Limbah cair yang dihasilkan akan ditampung ke dalam bak-bak yang kemudian akan diangkut oleh pihak ketiga yang berkerjasama.

Seperti yang disampaikan Bapak Ujang, pengelolaan limbah padat yang dilakukan oleh pabrik merupakan suatu tindakan yang dilakukan terhadap limbah atau limbah padat yang dihasilkan oleh pabrik mulai dari pengumpulan, pengangkutan, penyimpanan, dan pengelolaan hingga tahap akhir (yaitu pemusnahan). Pabrik memisahkan sampah basah dari sampah kering. Buat tempat sampah terpisah untuk sampah organik dan anorganik, pantau secara visual proses pengumpulan sampah, dan kumpulkan sampah atau sampah sesuai jadwal yang telah ditentukan untuk menghindari bau tak sedap. Tempat sampah disediakan agar tidak berserakan dan terbawa arus saat sampah atau sampah dikumpulkan di saluran air, agar tidak mencemari tanah dan mencemari lingkungan.Pengemasan limbah B3 sebelumnya ditempatkan di TPS limbah B3. Hal tersebut dilakukan untuk menghindari degradasi keindahan lingkungan. Pabrik tersebut diserahkan kepada pihak ketiga untuk mengelola limbah B3 dan non B3 serta memelihara TPS B3 dan non-B3 sesuai ketentuan yang bertujuan untuk mencegah potensi gangguan kesehatan. Pengelolaan dilakukan sesuai ketentuan dalam SOP yang dikeluarkan PT. Pertanian Global Agri Bisnisindo.

\section{Akuntansi Lingkungan Di Pabrik PT. Universal Agri Bisnisindo}

Perusahaan perlu menerapkan akuntansi lingkungan untuk membantu kegiatan operasional, khususnya dalam pengelolaan limbah produksi. Akuntansi lingkungan merupakan bidang akuntansi yang dapat digunakan untuk mengidentifikasi, mengidentifikasi, mengukur, mengevaluasi dan melaporkan akuntansi lingkungan (Nilasari, 2014). Hal ini membutuhkan kesadaran perusahaan atau organisasi lain yang memanfaatkan lingkungan, oleh karena itu akuntansi lingkungan menjadi penting karena menuntut perusahaan untuk mengelola lingkungan sekitarnya dengan baik. Menurut (Burhany, 2014,hlm. 1-8), penerapan akuntansi lingkungan bertujuan untuk menghasilkan informasi yang berkaitan dengan lingkungan. Oleh karena itu, bagi perusahaan yang menerapkan akuntansi lingkungan, menghasilkan informasi ini akan menimbulkan biaya tambahan. Penting bagi perusahaan atau organisasi lain untuk meningkatkan upaya mereka dalam mempertimbangkan kondisi konservasi dan lingkungan secara berkelanjutan. Sebagai bentuk tanggung jawab organisasi (pabrik), bertujuan untuk menyelesaikan masalah limbah operasional yaitu mengelola limbah operasional atau hasil produksi secara sistematis melalui proses yang memerlukan biaya khusus, yang memungkinkan perusahaan mengalokasikan nilai biaya tersebut dalam pencatatan keuangan perusahaan. Biaya yang dikeluarkan perusahaan terkait dengan kerusakan lingkungan yang disebabkan oleh perlindungan atau pemeliharaan. 
Ibu Lena juga mengungkapkan hal ini sebagai manajer akuntansi:

Biaya akuntansi lingkungan yang dilakukan oleh pabrik mengacu pada biaya yang dikeluarkan oleh kegiatan operasi pabrik, yang dirancang untuk mengelola dan mencegah kerusakan lingkungan sekitar pabrik, area pabrik dan limbah yang dihasilkan oleh pabrik. Pengeluaran ini dilakukan pada saat terjadi kerusakan atau untuk menghindari adanya pemborosan dalam kegiatan pabrik. Contoh biaya yang dikeluarkan adalah biaya jasa kebersihan, yang membersihkan area pabrik setiap saat agar karyawan dan tamu tetap nyaman. Konsep akuntansi lingkungan pabrik mendorong kemampuan orang untuk meminimalkan masalah lingkungan yang mereka hadapi. Ibu Lina mengungkapkan.

Jika akuntansi lingkungan diterapkan, maka sangat membantu untuk menjaga lingkungan dari limbah, khususnya limbah B3. Selain itu, pihak pabrik bermaksud memberikan rasa aman kepada karyawan / pekerja, tamu, dan masyarakat sekitar pabrik serta mencegah bahaya pemborosan. Berdasarkan penelitian yang dilakukan, biaya yang dikeluarkan oleh pabrik diklasifikasikan sebagai laporan keuangan pabrik. Ibu Lina menyampaikan hal tersebut sebagai manajer akuntansi. PSAK tidak menjelaskan secara jelas dan rinci hal-hal penting yang harus diungkapkan dalam laporan perusahaan. Sehingga dapat membuat sistem pencatatan di setiap perusahaan yang menguntungkan (seperti pabrik).

\section{Identifikasi Biaya Lingkungan Di Pabrik PT. Universal Agri Bisnisindo}

Organisasi akan memutuskan untuk melaksanakan aktivitas terkait dan berharap dapat mendukung keberlanjutan organisasi dengan mengidentifikasi peristiwa ekonomi. Dengan mengidentifikasi transaksi bisnis perusahaan dalam kurun waktu tertentu, identifikasi merupakan tahapan pertama dari siklus akuntansi. Untuk pertama kalinya, pabrik menentukan biaya lingkungan untuk mengelola tindakan pencegahan yang terjadi dalam kegiatan operasional, yaitu mengidentifikasi dampak negatif. PT. Universal Agri Bisnisindo dapat mengidentifikasi semua kegiatan proses produksi dan non produksi yang dapat menimbulkan dampak lingkungan dan mengalokasikan biaya untuk pengelolaan lingkungan. Berdasarkan wawancara yang dilakukan dapat diketahui bahwa biaya yang dikeluarkan oleh pabrik adalah biaya pengangkutan sampah selama proses produksi, biaya instalasi pengolahan limbah, biaya daur ulang sampah, biaya jasa kebersihan, dan biaya izin pengangkutan sampah atau sampah. Ada juga tagihan listrik untuk pengoperasian mesin pengelolaan sampah, namun karena tagihan listrik tidak dapat dihitung secara terpisah, maka tagihan listrik tersebut akan ditambahkan ke total tagihan listrik bersama dengan total tagihan listrik pabrik.

Pabrik memiliki kebijakan tersendiri dalam menentukan biaya pengelolaan limbah. Tidak ada standar khusus untuk mengatur pengelolaan pencatatan biaya dampak negatif yang ditimbulkan oleh sisa hasil operasi perusahaan, sehingga pabrik cocok untuk mengidentifikasi biaya terkait pengelolaan sampah dan melaporkan biaya pengelolaan sampah ke laporan operasi pabrik. . Penentuan biaya yang dikeluarkan 
dalam proses pengelolaan sampah akan membantu perusahaan dalam membuat laporan keuangan dan dijadikan sebagai bentuk tanggung jawab pabrik..

\section{Pengakuan Biaya Lingkungan Di Pabrik PT. Universal Agri Bisnisindo}

Jika produsen memperoleh manfaat dari biaya nominal yang terjadi, biaya tersebut akan diakui dalam akun. Ketika suatu peristiwa ekonomi yang dikonfirmasi memperoleh manfaat dari pengeluaran untuk pemeliharaan lingkungan, hal itu akan diakui sebagai akun dan disebut biaya. Pabrik PT. Universal Agri Bisnisindo mengakui biaya lingkungan apabila sudah memberikan manfaat bagi Pabrik PT. Universal Agri Bisnisindo. Ibu Lina juga mengungkapkan bahwa pencatatan dalam transaksi biaya pengelolaan lingkungan menggunakan metode akrual basis jadi contohnya sebagai berikut:

Pengiriman :

Biaya pengangkutan limbah

Rp. $x x x$

Utang pengangkutan limbah

Rp. $x x x$

Mendapat Bukti :

Utang pengangkutan limbah

Rp.xxx

Bank

$R p . x x x$

Menurut penjelasan Bu Lina, dalam pencatatannya perusahaan menggunakan basis akrual, sehingga biaya pengangkutan limbah sudah terkonfirmasi, bahkan jika belum dilunasi, tetap menjadi hutang perusahaan. Biaya tersebut baru dibayarkan setelah mendapat bukti dari pihak ketiga bahwa limbah tersebut telah dihancurkan dengan jangka waktu pembayaran 7 hari setelah bukti keluar. Untuk ledger dan laporan keuangan bagian biaya limbah ada di bagian lampiran.

\section{Pengukuran Biaya Lingkungan Di Pabrik PT. Universal Agri Bisnisindo}

Menurut penelitian Kusumawati (2015,hlm. 1-6), biaya pengelolaan sampah ditentukan berdasarkan setiap kilogram sampah atau sampah yang dikelola. Namun, karena belum diukur, belum diketahui pasti berapa unit biaya setiap pengelolaan sampah. Pengukuran tersebut terkait dengan penentuan jumlah rupiah yang tercatat pertama kali pada saat transaksi terjadi. Saat menentukan biaya pengelolaan sampah, pabrik menentukan besaran rupiah yang harus dibayar dengan menggunakan satuan mata uang berdasarkan tiap kilogram sampah yang diolah. Setiap perusahaan memiliki standar pengukuran yang berbeda-beda, sehingga perlu dilakukan pengukuran untuk menentukan apakah akan mengalokasikan pembiayaan sesuai dengan status perusahaan yang bersangkutan. Ibu Lina juga menyampaikan dalam pengukuran, pabrik UAB mengacu pada hasil realisasi anggaran periode sebelumnya dan menggunakan satuan mata uang saat mengukur biaya pengelolaan limbah dan total biaya yang dikeluarkan tidak jauh berbeda dengan realisasi pada periode sebelumnya. Menurut (Suwardjono, 2013), pengukuran adalah menentukan banyaknya benda atau satuan ukuran untuk menunjukkan makna tertentu dari benda tersebut. Biasanya, perusahaan menggunakan unit mata uang yang telah ditentukan 
dan jumlah uang yang dikeluarkan untuk mengukur biaya pengelolaan lingkungan perusahaan. Dapatkan jumlah dan nilai yang tepat sesuai dengan kebutuhan aktual perusahaan di setiap periode. Sejauh ini, belum ada metrik yang terkait dengan biaya lingkungan yang telah ditentukan. Oleh karena itu, pengukuran biaya lingkungan lebih didasarkan pada kebijakan perusahaan saat ini. Hal ini juga diungkapkan oleh Mulyani (2013), meskipun belum ada standar standar pengukuran biaya lingkungan (dalam hal biaya pengelolaan limbah), namun standar pengukuran biaya lingkungan mengacu pada kebijakan yang diterapkan oleh perusahaan.

\section{Penyajian Biaya Lingkungan Di Pabrik PT. Universal Agri Bisnisindo}

Biaya pengelolaan limbah tercantum dalam laporan operasi pabrik. Biaya yang timbul dalam pengelolaan lingkungan didaftar bersama dengan biaya satuan lainnya. Karena tidak ada peraturan atau standar standar untuk nama akun atau akun yang digunakan untuk alokasi pembiayaan lingkungan, nama yang berbeda dapat digunakan untuk representasi biaya lingkungan dalam laporan keuangan perusahaan. Pabrik juga menampilkan biaya lingkungan dalam laporan keuangan umum.

Berdasarkan hasil wawancara dan penelitian tentang ekspresi biaya lingkungan diketahui PT. Universal Agri Bisnisindo mengedepankan biaya lingkungan dan biaya terkait pengelolaan limbah. Penyajian dilakukan bersama sebagai biaya sub-operasi. Dengan pengusulan biaya pengelolaan limbah tersebut, pembaca laporan keuangan akan lebih mudah memahami dan membandingkan kinerja yang dicapai oleh pabrik.

\section{Pengungkapan Biaya Lingkungan Di Pabrik PT. Universal Agri Bisnisindo}

Tahap terakhir dari proses akuntansi adalah pengungkapan. Melalui pengungkapan, entitas memberikan transparansi kepada publik. Pengungkapan juga memberikan informasi yang tidak dapat diberikan dalam bentuk data keuangan. Tidak ada standar khusus untuk pengungkapan terkait dengan biaya lingkungan yang dikeluarkan oleh pabrik, namun akan lebih baik jika pabrik melakukan pengungkapan. Pengungkapan transaksi terkait kegiatan pengelolaan limbah pabrik sangat penting dilakukan agar pemangku kepentingan dapat memperoleh informasi yang berguna, terutama dalam laporan keuangan yang disediakan. Pelaksanaan kegiatan pengelolaan limbah pabrik belum diperhitungkan secara tersendiri dalam laporan biaya lingkungan khusus. Ibu Lina menjelaskan bahwa pihak pabrik sudah menyajikan kegiatan mengenai biaya pengelolaan limbah yang dilakukan oleh pihak pabrik dan biaya - biaya tersebut harus diungkapkan. Biaya pengelolaan limbah diungkapkan ke dalam laporan operasional atau laporan laba rugi pabrik.

Pengungkapan adalah untuk melengkapi atau meningkatkan proses atau siklus akuntansi lingkungan. Biaya yang dikeluarkan oleh pabrik dalam kegiatan pengelolaan limbah diungkapkan dalam operasi atau laporan laba rugi. Pengungkapan ini berguna untuk memahami setiap transaksi yang terjadi selama kegiatan pengelolaan limbah pabrik. Pada dasarnya PT. Universal Agri Bisnisindo telah mengidentifikasi, mengkonfirmasi, mengukur, menyajikan dan mengungkapkan laporan keuangan. 


\section{Temuan pada Penelitian di Pabrik PT UAB}

Pekerjaan penelitian pabrik PT UAB dimulai dengan memahami pengetahuan dasar pabrik pakan ternak, dan gambaran singkat pabrik setelah memahami bagaimana pabrik mengelola limbah yang dihasilkan. Mencari informasi tentang aplikasi akuntansi lingkungan mulai dari identifikasi, identifikasi, pengukuran, penyajian dan pelaporan. Menurut pengelola keuangan pabrik, menurut penelitian yang dilakukan oleh pabrik PT UAB, pengertian akuntansi lingkungan yang berlaku pada pabrik sangat membantu dalam menghitung biaya lingkungan yang dikeluarkan oleh pabrik dan membantu pabrik mengambil keputusan, khususnya dalam pengelolaan lingkungan, dan memudahkan pemangku kepentingan untuk memahami tanggung jawab lingkungan pabrik.

\section{Pembahasan}

Penerapan Akuntansi Lingkungan Dalam Upaya Pencegahan Limbah Pabrik PT. Universal Agri Bisninindo

Untuk menangani pemborosan dalam operasinya, pabrik perlu mengalokasikan biaya di antaranya. Menghitung biaya limbah membutuhkan sistem akuntansi yang tepat. Pembuangan limbah akibat beroperasinya pabrik sangat penting dilakukan untuk mengendalikan tanggung jawab perusahaan terhadap lingkungan. Pengalokasian biaya pengelolaan sampah selama proses produksi dapat memberikan insentif bagi pengelola dan bawahannya untuk mengurangi pencemaran yang disebabkan oleh proses tersebut (Sari, 2017). Akuntansi lingkungan adalah bidang akuntansi yang dapat digunakan untuk mengidentifikasi, mengidentifikasi, mengukur, mengevaluasi, menyajikan dan mengungkapkan biaya lingkungan. Dalam hal ini pencemaran dan limbah produksi pabrik merupakan contoh dampak negatif dari operasi pabrik.Operasi pabrik memerlukan sistem akuntansi lingkungan untuk mengontrol akuntabilitas pabrik. Mengenai kebijakan yang diterapkan oleh pabrik, Bapak Bireven mengungkapkan bahwa di pabrik ini, kebijakan yang diambil mengacu kepada perda yang berlaku, jadi bisa dibilang perusahaan mengikuti standar dari perda tersebut. Penerapan akuntansi lingkungan inipun yang nantinya akan diberikan kepada stakeholder, untuk membuktikan tanggung jawab pabrik terhadap lingkungannya dan sudah memenuhi peraturan daerah setempat

\section{Tanggung Jawab Sosial Pabrik PT. Universal Agri Bisnisndo}

Pencemaran akibat limbah produksi pabrik merupakan salah satu contoh dampak negatif dari kegiatan pabrik, kegiatan pabrik memerlukan sistem akuntansi lingkungan sebagai dampak negatif dari pengendalian tanggung jawab pabrik. Tanggung jawab sosial adalah kepedulian lingkungan untuk tanggung jawab sosial perusahaan. Jika perusahaan bertanggung jawab terhadap lingkungan dimana perusahaan tersebut berada maka akan ada tanggung jawab sosial. Kemajuan teknologi telah menciptakan insentif untuk melindungi lingkungan antara pemerintah dan perusahaan sehingga keberlanjutan ekonomi sumber daya alam dapat dipertahankan. Setiap organisasi atau perusahaan yang menghasilkan produk atau jasa sebagai output dari kegiatan usahanya secara otomatis bertanggung jawab 
terhadap lingkungan sekitar perusahaan. Masyarakat merupakan bagian penting dari keberlangsungan operasional pabrik. Melalui masyarakat sekitar pabrik, keuntungan dan produktivitas pabrik dapat ditingkatkan. Dengan demikian, pabrik dapat bertahan atau melanjutkan operasinya dengan dukungan masyarakat. Tanggung jawab atas masalah terletak pada bagaimana organisasi mengintegrasikan masalah lingkungan. Hal ini berdasarkan pernyataan dari Pak Ujang sebagai bagian dari IPAL yang menyatakan bahwa pihak pabrik sudah menjaga lingkungannya dengan cukup baik, dilihat dari tidak adanya laporan dari masyarakat sekitar mengenai pencemaran lingkungan yang ditimbulkan oleh pabrik pakan ternak PT Universal Agri Bisnisnindo. Hal ini juga didukung dengan pernyataan ibu Ayu yang tinggal di sekitar pabrik sebagai pedagang jika beliau tidak merasa terganggu dengan adanya pabrik ini, terutama untuk masalah lingkungan dan masalah limbah sampah pabrik bau- bau pun tidak ada.

Menurut hasil wawancara dengan banyak pihak, PT dapat diturunkan. Universal Agri Bisnisindo telah mengelola sampah dengan baik dan aman bagi lingkungan sekitar pabrik, karena pabrik memiliki rasa tanggung jawab dan harus memenuhi tanggung jawabnya kepada masyarakat. Pabrik juga harus menyatakan apakah perusahaan beroperasi sesuai dengan norma, aturan dan batasan yang ada di masyarakat. Dengan berjalannya waktu maka dampak dari pabrik akan semakin besar, dan akan berdampak pada kehidupan masyarakat sekitar pabrik, sehingga pabrik harus bertanggung jawab terhadap lingkungan dan masyarakat. Menurut warga yang tinggal di sekitar PT. Universal Agri Bisnisindo, mereka tidak ambil pusing dengan keberadaan pabrik pakan ternak ini, pabrik tersebut telah menerapkan pengelolaan limbah dengan baik, dan tidak ada limbah yang menumpuk akan menimbulkan bau tidak sedap dalam operasinya. Kepedulian pabrik terlihat dari upaya pabrik dalam memenuhi tanggung jawab sosialnya terhadap lingkungan sekitar.

\section{Simpulan}

\section{Kesimpulan}

Mengetahui penerapan akuntansi lingkungan di Pabrik Pakan Ternak PT merupakan tujuan dari penelitian ini. Universal Agri Bisnisindo dalam upaya mengatasi masalah limbah yang dapat mencemarkan lingkungan. kesimpulan berdasarkan penelitian ini adalah Pabrik Pakan Ternak PT. Universal Agri Bisnisindo sudah mencegah masalah limbahnya dengan cukup baik. Mempunyai mesin IPAL yang berfungsi mencegah atau mengurangi terjadinya limbah yang keluar dari proses produksi. Walaupun peralatan IPAL yang dipakai belum memadai, tetapi perusahaan dapat mengatasi dan mengelola limbahnya dengan baik.

Pabrik Pakan Ternak PT. Universal Agri Bisnisindo telah menerapkan akuntansi lingkungan yaitu dengan melakukan identifikasi biaya, Konfirmasi biaya, pengukuran biaya, penyajian biaya dan pengungkapan biaya merupakan tahapan perlakuan akuntansi pengelolaan limbah pabrik. Beban terkait dengan manajemen PT. Universal Agri Bisnisindo terdiri dari biaya IPAL, biaya retribusi dan perizinan jalan untuk pengangkutan sampah dan limbah, biaya pemeliharan peralatan dan mesin IPAL, biaya cleaning service termasuk pekerja bagian pengelola limbah. Pabrik telah 
menentukan biaya yang timbul dalam proses pengelolaan limbah dan mengakui biaya lingkungan yang timbul sebagai biaya operasi dengan metode akrual. Pengukuran biaya pengelolaan sampah di pabrik didasarkan pada kilogram setelah pengolahan. Gunakan unit mata uang untuk menentukan jumlah biaya yang harus dibayar. PT. Universal Agri Bisnisindo mengedepankan biaya lingkungan dan biaya terkait pengelolaan limbah. Penyajian dan pengungkapan dilakukan bersama-sama sebagai biaya sub-operasi dalam akun beban administrasi dan umum.

Berdasarkan dari penelitian yang dilakukan, Pabrik PT UAB sudah menjalankan kewajiban konstruktif yang merupakan tanggung jawab suatu entitas untuk memelihara lingkungan sekitarnya dengan kebijakan perusahaan ini, seperti yang disebutkan dalam PSAK No. 57 dan dalam PSAK No. 33 perihal pengeluaran biayabiaya pengelolaan lingkungannya seperti biaya pengelolaan limbah untuk mengurangi dan mengendalikan dampak negatif dari kegiatan pabrik yang dapat mencemarkan lingkungan, sudah dilaksanakan oleh PT.UAB.

\section{Keterbatasan}

Peneliti menyadari bahwa hasil penelitian masih memiliki keterbatasan, yaitu selain keterbatasan waktu untuk melakukan wawancara dengan beberapa narasumber, juga kurangnya literatur seperti ketentuan - ketentuan atau standar yang ditetapkan mengenai akuntansi lingkungan dalam PSAK.

\section{Saran}

Berdasarkan beberapa kesimpulan dan batasan penelitian diatas maka peneliti mencoba memberikan saran khususnya perlunya mempelajari lebih mendalam mengenai akuntansi lingkungan dilihat dari adanya isu-isu pencemaran lingkungan yang membutuhkan perhatian dan penanganan khusus, Sehingga kita dapat mengambil langkah yang tepat untuk melindungi dan melindungi lingkungan, walaupun memang belum ada PSAK yang mengatur secara detail, tetapi pemerintah sudah mengatur lewat Undang - Undang dan perda untuk menjaga, melindungi, dan melestarikan lingkungan hidup. Dilihat dari masalah tentang kurangnya pengelola limbah yang kurang memadai pabrik PT. Universal Agri Bisnisindo sebaiknya memiliki IPAL yang memadai, agar lebih terjaminnya dalam pengelolaan limbah untuk mencegah terjadinya pencemaran lingkungan dan juga untuk keberlangsungan dan nama baik perusahaan. 


\section{Daftar Pustaka}

Arif, Z. (2014). Pengelolaan Limbah Berkelanjutan. Yogyakarta: Graha Ilmu.

Burhany, D. I. (2014). Pengaruh Implementasi Akuntansi Lingkungan Terhadap Kinerja Lingkungan dan Pengungkapan Informasi Lingkungan (Studi pada Perusahaan Pertambangan Umum yang Mengikuti PROPER Periode 2008-2009). Indonesia Journal of Economics and Business.

Gray, R., Walters, D., Bebbington, J., \& Thompson, I. (1995). The greening of enterprise: An exploration of the (NON) role of environmental accounting and environmental accountants in organizational change. Critical Perspectives on Accounting. https://doi.org/10.1006/cpac.1995.1021

Hadi, S. (2012). Analisis Penerapan Akuntansi Lingkungan pada PT. Istana Cipta Sembada Banyuwangi. Skripsi.

Ikhsan, A. (2008). Akuntansi Lingkungan dan Pengungkapannya. In Graha Ilmu.

Kusumawati, T. (2015). Perlakuan Akuntansi Atas Pengelolaan Limbah Pada RSUD Dr. R. Koesma Tuban. Skripsi: Fakultas Ekonomi Universitas Jember.

Nilasari, F. (2014). Analisis Penerapan Akuntansi Lingkungan Terhadap Pengelolaan Limbah. Journal Akuntansi.

Pemerintah Republik Indonesia. (2019). Peraturan Pemerintah Republik Indonesia Nomor 47 Tahun 2012 Tentang Tanggung Jawab Sosial Dan Lingkungan Perseroan Terbatas. Journal of Chemical Information and Modeling.

Suwardjono. (2013). Teori Akuntansi Perekayasaan Pelaporan Keuangan, Edisi Ketiga, Yogyakarta: BPFE. In 2020.

Undang-Undang Republik Indonesia. (2009). Undang-Undang Republik Indonesia Nomor 32 Tahun 2009 Tentang Perlindungan dan Pengelolaan Lingkungan Hidup. Aspectos Generales De La Planificación Tributaria En Venezuela.

\section{Lampiran}

\section{Lampiran 1. Manuskrip Wawancara}

\section{Pelaksanaan Wawancara}

$\begin{array}{lll}\text { Key Informan } & \text { : Ibu Lina } & \text { Kode Informan : L } \\ \text { Key Informan } & \text { : Pak Ujang } & \text { Kode Informan : U } \\ \text { Informan Pendukung: Pak Bireven } & \text { Kode Informan : B } \\ \text { Informan Pendukung: Ibu Ayu } & \text { Kode Informan : A }\end{array}$

Jabatan Pekerjaan L : Manajer Akuntan PT UAB

Jabatan Pekerjaan U : Staff bagian IPAL PT UAB

Jabatan Pekerjaan B : Kepala bagian hukum PT UAB

Jabatan Pekerjaan A : Pemilik rumah makan sekitar PT UAB

Tempat

: Pabrik PT Universal Agri Bisnisindo

Waktu

: 27 November 2019 
B : Selamat siang, Pak, Bu, perkenalkan nama saya Billy Josiah mahasiswa UPN Veteran Jakarta jurusan Akuntansi, tujuan saya ke sini untuk melakukan riset skripsi saya dengan judul Analisis Penerapan Akuntansi Lingkungan pada Pabrik Pakan Ternak Terhadap Pengelolaan Limbah Pabrik Pakan Ternak PT UAB. Baik, langsung kita mulai aja ya.

U : Oke silahkan Mas.

P : Pertama saya ingin menanyakan tentang permasalahan apa yang berhubungan dengan pengelolaan lingkungan perusahaan ini, khususnya bagian limbahnya.

U : Ya untuk itu baru-baru ini kami baru menyewa konsultan lingkungan untuk mengecek itu. Nanti akan saya email aja ke masnya ya temuannya.

P : Apakah ada masalah dalam pengelolaan lingkungan pada pabrik ini?

U : Untuk masalah seperti itu ada, seperti pabrik ini membuang air limbah ke badan air penerima yang berdekatan dengan Sungai Cileungsi tanpa izin yang diperlukan, juga kurangnya pemantauan lingkungan, selain itu ya juga kurangnya fasilitas penyimpanan limbah berbahaya sementara. Tetapi kita sebenarnya sudah berusaha untuk memelihara lingkungan, cuman ada beberapa fasilitas yang kurang dan kita sedang mempersiapkan fasilitas fasilitas tersebut.

P : Sedangkan untuk biaya-biaya yang dikeluarkan untuk mengatasi limbah tersebut bisa diketahui atau dilihat di mana ya, $\mathrm{Bu}$ ?

L : Untuk pelaporan pengeluaran biaya mengenai mengatasi masalah lingkungan di pabrik ini, bisa kamu lihat di beban administrasi dan umum perusahaan. Di laporannya bisa kamu lihat ada beban pajak dan perizinan, di 
situ termasuk biaya untuk perizinan untuk pengangkutan limbah dan juga biaya jasa untuk pihak yang mengelola limbah kita.

P : : Untuk Limbah yang dihasilkan pabrik ini ada jenisnya apa ya Pak?

U : Untuk limbah yang pabrik ini hasilkan itu ada 2 jenis mas, ada limbah cair sama ada limbah padat yang di dalamnya termasuk limbah B3 juga.

P : Bagaimana ya Pak untuk pengelolaannya?

U : Pengelolaan limbah cair kita sebenernya tidak telalu ribet, jadi limbah cair tersebut nantinya akan ditampung ke dalam bak-bak atau drum-drum begitu, memang dipisah antara limbah cair yang mengandung b3 dan yang tidak, sederhana aja sih, yang penting limbahnya tidak berceceran, setelah itu limbah tersebut akan diangkut jika penampungannya sudah penuh

U : Ga jauh berbeda dengan pengeolaan limbah cair sih ya, hanya asal limbahnya saja dari mana dan untuk tempat penampungannya dipisahkan dengan limbah cair tentunya, kita juga menyiapkan TPS yang memadai ya sesuai ketentuan.

$\mathrm{P} \quad$ : Penerapan akuntansi lingkungan di perusahaan ini seperti apa $\mathrm{Bu}$ ?

L : biaya lingkungan itu sebenernya biaya yang timbul dari kegiatan operasional pabrik yang bertujuan untuk mengelola dan mencegah terjadinya kerusakan di lingkungan sekitar pabrik, baik itu limbah, area pabrik ,dan yang lainnya. Jadi nanti kalau kamu butuh manifestnya, penawaran pengangkutan dari pihak ketiga boleh nanti saya kasih. 
P : Menurut Ibu apakah penerapan akuntansi lingkungan itu berguna bagi perusahaan?

L $\quad$ : Akuntansi lingkungan jika diterapkan di lingkungan pabrik itu sangat baik. Apalagi kami pihak pabrik juga memiliki niat agar lingkungan sekitar pabrik tidak tercemar oleh kegiatan pabrik ini dan tidak terganggu dengan adanya pabrik ini karena kami melakukan pengelolaan lingkungan.

P : Biaya-biaya yang teridentifikasi dikeluarkan oleh pabrik untuk mengatasi lingkungannya ini apa aja ya Bu?

L : Biaya yang dikeluarkan oleh pihak pabrik yaitu biaya IPAL, biaya pengangkutan sampah proses produksi, biaya retribusi sampah, biaya cleaning service, biaya perizinan pengangkutan sampah atau limbah. Ada juga ya biaya listrik buat mengoperasikan mesin pengelola limbahnya, tetapi biaya listrik diakumulasikan ke dalam biaya listrik secara keseluruhan dengan biaya listrik pabrik secara umum, karena ga mungkin untuk biaya listrik secara tersendiri gitu.

P : Untuk pengakuan biayanya nih, itu seperti apa ya Pak, Bu?

U : Pertama ada penawaran dulu dari pihak ketiga, setelah itu apabila perusahaan setuju dengan penawaran tersebut maka pihak ketiga akan mengangkut limbah tersebut, kita baru akan membayar setalah bukti keluar dari pihak ketiga yaitu kita sedang bekerjasama dengan PT. Prasadha Pamunah Limbah Industri, mengenai proses penghancuran limbah. Setelah itu baru akan kita bayarkan paling lama 7 hari setelah keluar bukti tersebut keluar.

L : Baru bisa disebut sebagai biaya apabila sudah mendapat manfaat walaupun kas belum dikeluarkan. Metode akuntansi yang kita pakai itu metode Akrual 
basis dek, dimana pengakuan dilakukan saat udah mendapat manfaat walaupun belum dibayarkan secara tunai. Misalnya pada saat kita mengirimkan limbah ke PT. Prasadha Pamunah Limbah Industri, disebut sebagai biaya dan baru dibayarkan setelah mendapat bukti bahwa limbah tersebut telah dihancurkan, nanti untuk ledgernya sama laporan keuangan untuk biayanya akan saya kasih liat.

P : Bagaimana untuk pengukuran atas pengelolaan limbahnya?

L : Dalam pengukuran kita mengacuh pada hasil realisasi anggaran periode sebelumnya, jumlahnya sih sedikit berbeda jadi tidak berbeda dengan nilai realisasi periode sebelumnya.

$\mathrm{P} \quad$ : Untuk penyajian atas biaya pengelolaan limbahnya itu seperti apa ya $\mathrm{Bu}$ ?

L : Untuk biaya pengelolaan limbah kami menyajikan secara bersama-sama ke dalam satu laporan keuangan, biaya disajikan ke dalam pos biaya operasional atau biaya umum ya. Tidak ada penyajian khusus atas biaya lingkungan yang terjadi.

$\mathrm{P} \quad$ : Laporan keuangan tersebut bagaimana untuk pengungkapannya ya $\mathrm{Bu}$, terutama untuk biaya pengelolaan limbah?

L : Kami sudah menyajikan kegiatan mengenai biaya pengelolaan limbah yang dilakukan oleh pihak pabrik dan ini biaya harus diungkapkan. Biaya pengelolaan limbah diungkapkan ke dalam laporan operasional atau laporan laba rugi pabrik.

P : Kebijakan yang diambil pabrik ini memiliki acuan kepada suatu peraturan tertentu atau bagaimana? 
B : Jadi di pabrik ini, kebijakan yang kita ambil mengacu kepada perda yang berlaku, jadi bisa dibilang kita mengikuti standar dari perda ini. Penerapan akuntansi lingkungan inipun yang nantinya akan kita berikan kepada stakeholder, untuk membuktikan tanggung jawab pabrik terhadap lingkungannya dan sudah memenuhi peraturan daerah setempat.

P : Jadi menurut Bapak dan Ibu, bagaimana sih tanggung jawab pabrik ini terhadap lingkungan sekitarnya?

L : Pihak pabrik telah mengelola limbahnya dengan baik dan tidak mengganggu masyarakat di sekitar pabrik, karena kami memiliki tempat tersendiri untuk menampung sampah hingga batas tertentu untuk selanjutnya akan diangkut oleh pihak ketiga yang bersangkutan.

U : Kami telah menjaga kebersihan dengan baik karena kebersihan yang paling utama. Di pabrik ini bagian bersih-bersihnya sekitar 30 orang yang setiap hari bertugas membersihkan di pabrik. Dan selama saya bekerja di pabrik ya tidak ada keluhan dari masyarakat sekitar mengenai limbah yang di timbulkan dari aktivitas pabrik.

P : Selamat sore Ibu, izin mengganggu waktunya sebentar ya. Sebagai penjual yang memiliki rumah makan di daerah pabrik UAB ini, selama adanya pabrik ini apakah mengganggu lingkungan sekitar pabrik Bu? Mungkin seperti pencemaran lingkungannya?

A : Saya tidak merasa terganggu sih ya dengan adanya pabrik ini.Ya terutama untuk masalah lingkungannya sih ya baik-baik aja sih. Aman-aman aja sih kalau masalah limbah sampah pabrik bau- bau pun tidak ada

\section{Lampiran 2. Ledger Biaya Limbah PT UAB}




\begin{tabular}{|c|c|c|c|c|c|}
\hline Number & Date & Descript & Debit & Credit & Balance \\
\hline 50.200 .751 & 31-Dec-18 & SALDO PER 31/12/2018 & 0 & 0 & 0 \\
\hline 50.200 .751 & 17-Jan-19 & JASA ANG.LIMBAH IN.I1874415311 & 0 & \multicolumn{2}{|c|}{$7074000-7074000$} \\
\hline 50.200 .751 & 17-Jan-19 & JASA ANG.LIMBAH IN.I1874415311 & 4755300 & 0 & -2318700 \\
\hline 50.200 .751 & 17-Jan-19 & JASA ANG.LIMBAH IN.I1874415311 & 2089450 & 0 & -229250 \\
\hline 50.200 .751 & 17-Jan-19 & JASA ANG.LIMBAH IN.I18744 & 360250 & 0 & 131000 \\
\hline 50.200 .751 & 17-Jan-19 & IRO: JASA ANG.LIN & 7074000 & 0 & 7205000 \\
\hline 50.200 .751 & 05-Aug-19 & $\begin{array}{l}\text { AP INV: B.PENGOLAHAN LIMBAH B3 } \\
\text { ANGKUT: } 15\end{array}$ & 500000 & 0 & 0 \\
\hline 50.200 .751 & 05-Aug-19 & $\begin{array}{l}\text { AP INV: B.PENGOLAHAN LIMBAH B3 } \\
\text { ANGKUT: } 15\end{array}$ & 3000000 & 0 & 000 \\
\hline 0.200 .751 & 05-Aug-19 & $\begin{array}{l}\text { AP INV: B.PENGOLAHAN LIMBAH B3 } \\
\text { ANGKUT:15 }\end{array}$ & 1500000 & 0 & 1920500 \\
\hline 50.200 .751 & 05-Aug-19 & $\begin{array}{l}\text { AP INV: B.PENGOLAHAN LIMBAH B3 } \\
\text { ANGKUT:15 }\end{array}$ & 500000 & 0 & 19705000 \\
\hline
\end{tabular}

Lampiran 3. Laporan Keuangan PT UAB bagian Biaya Umum

\begin{tabular}{lcc}
\hline 50.200 .000 & -BIAYA UMUM & \\
\hline 50.200 .011 & -Biaya Air (PAM) & $5,294,868$ \\
\hline 50.200 .030 & -Biaya Telepon & $352,040,866$ \\
\hline 50.200 .040 & -Biaya Materai & $22,845,800$ \\
\hline 50.200 .050 & -Biaya Transportasi/ Taxi/ Bus / dll. & $172,891,970$ \\
\hline 50.200 .070 & -Biaya PBB , Surat Izin, Pemda & $1,302,485,227$ \\
\hline 50.200 .071 & -Biaya Pajak Air (P3 ABT) & $72,706,700$ \\
\hline 50.200 .080 & -Biaya Denda & $44,720,000$ \\
\hline 50.200 .090 & -Biaya Bensin/Solar & $1,387,763,761$ \\
\hline 50.200 .100 & -Biaya Asuransi & $1,956,280,767$ \\
\hline 50.200 .110 & -Biaya Perjalanan Dinas & $4,191,857,227$ \\
\hline 50.200 .140 & -Biaya Alat Tulis dan Cetakan & $251,115,560$ \\
\hline 50.200 .160 & -Biaya Sumbangan & $3,950,000$ \\
\hline 50.200 .170 & -Biaya Iuran dan Retribusi & $596,293,860$ \\
\hline 50.200 .180 & -Biaya Pos, Majalah, Surat Kabar & $75,589,310$ \\
\hline 50.200 .190 & -Biaya Entertainment & $2,037,259,074$ \\
\hline 50.200 .200 & -Biaya Pendidikan dan Seminar & $68,968,679$ \\
\hline
\end{tabular}




\begin{tabular}{ccc}
\hline 50.200 .210 & -Biaya Penelitian dan Pengembangan & $430,731,664$ \\
\hline 50.200 .220 & -Biaya Sewa & $738,056,116$ \\
\hline 50.200 .751 & -Biaya Limbah & $19,705,000$ \\
\hline 50.200 .752 & -Biaya Imbalan Kerja & $4,119,790,484$ \\
\hline 50.200 .770 & -Rugi Atas Kehilangan Barang & $4,203,500$ \\
\hline 50.200 .990 & -Biaya Lain-lain & 20,000 \\
\hline & TOTAL - BIAYA UMUM & $17,854,570,433$ \\
\hline
\end{tabular}

\section{Lampiran 4. Lanjutan SOP PT UAB}

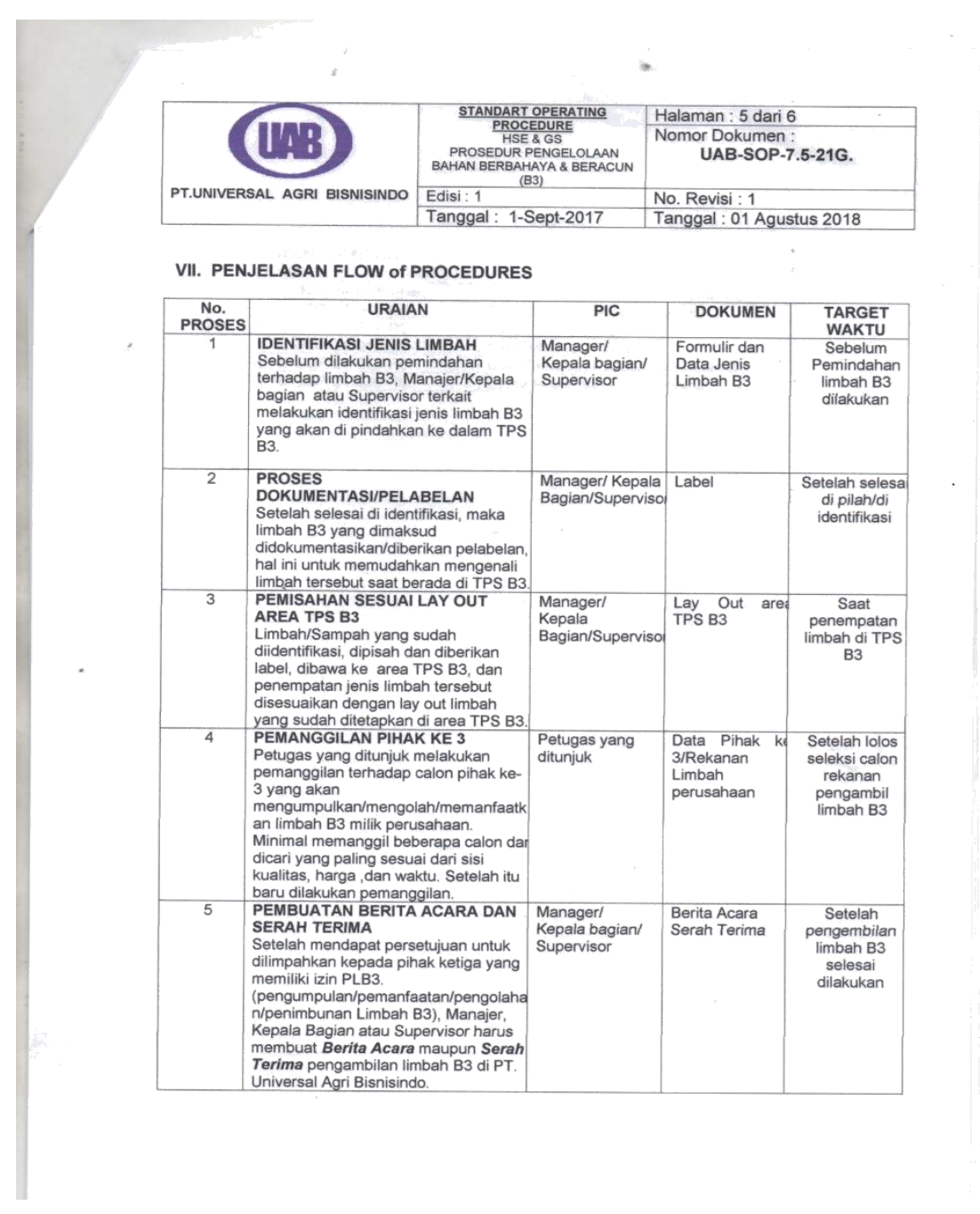

